\title{
NDRG4 hypermethylation is a potential biomarker for diagnosis and prognosis of gastric cancer in Chinese population
}

\author{
Xiaoying Chen ${ }^{1}$, Yong Yang ${ }^{1}$, Jing Liu ${ }^{1}$, Bin $\mathrm{Li}^{1}$, Yan $\mathrm{Xu}^{1}$, Cong $\mathrm{Li}^{2}$, Qi Xu ${ }^{2}$, Guili Liu${ }^{1}$, \\ Yingmin Chen ${ }^{1}$, Jieer Ying ${ }^{2}$, Shiwei Duan ${ }^{1}$ \\ ${ }^{1}$ Medical Genetics Center, School of Medicine, Ningbo University, Ningbo, Zhejiang 315211, China \\ ${ }^{2}$ Department of Medical Oncology, Zhejiang Cancer Hospital, Hangzhou, Zhejiang 310022, China \\ Correspondence to: Shiwei Duan, email: duanshiwei@nbu.edu.cn \\ Jieer Ying, email: jieerying@aliyun.com \\ Keywords: gastric cancer, N-Myc downstream regulated gene 4, DNA methylation, prognosis, diagnosis \\ Received: September 27, $2016 \quad$ Accepted: November 23, $2016 \quad$ Published: December 22, 2016
}

\section{ABSTRACT}

In order to assess whether N-Myc downstream regulated gene 4 (NDRG4) methylation was associated with the diagnosis and prognosis of gastric cancer, we measured the methylation of NDRG4 promoter and gene body regions among 110 gastric cancer patients using quantitative methods (MethyLight and pyrosequencing). Both NDRG4 promoter and gene body methylation levels were increased in tumor tissues than paired adjacent normal tissues $(P<0.001)$. NDRG4 gene body methylation was found to be significantly associated with age and tumor differentiation. NDRG4 promoter hypermethylation was proved to be a predictor of poor overall survival. However, opposite result was observed among The Cancer Genome Atlas (TCGA) cohort. The findings from gastric cell lines and public databases have suggested that NDRG4 methylation level was inversely associated with NDRG4 transcription level. Subsequent luciferase reporter gene assay showed that promoter CpG island but not gene body CpG island was able to upregulate gene expression. Collectively, NDRG4 promoter hypermethylation contributed to the risk of gastric cancer and predicted a poor prognosis in Chinese gastric cancer patients. Moreover, the combined methylation levels of NDRG4 promoter and gene body served as diagnostic biomarkers in gastric cancer.

\section{INTRODUCTION}

Gastric cancer is the third leading cause of cancerrelated mortality and the fourth most prevalent cancer in the world [1]. In China, gastric cancer is the second commonly diagnosed cancer, accounting for 679,100 novel cases and 498,000 cancer-associated mortalities from 2009 to 2011 [2]. The incidence of gastric cancer has a male : female ratio of approximately 2:1 [2]. And the majority (about $90 \%$ ) of gastric cancer belongs to the pathological subtype of adenocarcinoma [3]. Surgical resection remains the primary treatment for gastric cancer; however, the five-year survival rate for late stage gastric cancer rarely exceeds $5 \%[4,5]$. Tumor node metastasis (TNM) staging classification is the most common tool in the prediction of gastric cancer prognosis. However, the latest edition of the TNM classification couldn't satisfy the exact diagnosis due to the heterogeneous clinical behavior of gastric cancer [6,7]. Since peritoneal dissemination and local/distal metastases often occur in the late stages of gastric cancer, early diagnosis is beneficial and critical for the prevention of gastric cancer $[8,9]$.

Epigenetic abnormalities are considered as a significant event in the progression of cancers, such as colorectal cancer [10], lung cancer [11], esophageal cancer [12], as well as gastric cancer [13]. DNA methylation is an important epigenetic modification, and DNA methylation of cytosine-phosphate-guanine island (CGI) leads to the inappropriate silencing of tumor suppressor genes in the cancer initiation, progress, invasion and metastasis [14]. Aberrant methylation of tumor suppressor genes in gastric tissues and blood samples has been proposed as diagnostic and prognostic markers for gastric cancer $[2,13,15,16]$. 
N-Myc downstream regulated gene 4 (NDRG4) is located on chromosome 16q21-22.1 and contains 17 exons and 16 introns. It encodes a member of the N-myc downregulated gene family, involved in modulating cell proliferation, invasion, migration and angiogenesis in human cancers [17-20]. NDRG4 acts as a candidate tumor suppressor gene whose expression is frequently repressed by its promoter methylation in colorectal cancer [21]. Previous study has showed that the poor outcome of patients with glioblastoma was associated with $N D R G 2$ methylation and reduced expression [22]. NDRG2 and $N D R G 4$ belong to one subfamily based on sequence homology [23]; however, the role of NDRG4 methylation in gastric cancer is largely unknown.

In current study, we extract available The Cancer Genome Atlas (TCGA) data for discovering potentially risk sites and assess the NDRG4 methylation level in gastric cancer patients to determine whether $N D R G 4$ methylation is associated with the gastric cancer risk. Additionally, we explore the prognostic value of $N D R G 4$ methylation in gastric cancer patients and integrate TCGA clinical data for validating the results that we found in Chinese population.

\section{RESULTS}

\section{The detection of NDRG4 hypermethylation in gastric cancer patients}

Preliminary data mining in TCGA showed that the potentially risk $\mathrm{CpG}$ sites of $N D R G 4$ related with gene expression were enriched in two CGIs (CpG:192 at promoter and $\mathrm{CpG}: 41$ at gene body region, Figure 1). In TCGA data, there are 12 available $\mathrm{CpG}$ probes in promoter CGI and 5 available $\mathrm{CpG}$ probes in gene body CGI. All these $\mathrm{CpG}$ sites have a reverse correlation between DNA methylation and gene expression (all $\mathrm{r}<-0.10, P<0.05$, data not shown). Therefore, we chose the two fragments from promoter and gene body regions respectively for subsequent methylation test.

Most of previous NDRG4 methylation studies applied methylation specific PCR method which might be biased by incompletely bisulfite-converted sequences [24]. In the present study, two quantitative methods were used to measure $N D R G 4$ promoter and gene body methylation levels with internal controls. We have measured the methylation of NDRG4 $\mathrm{CpG}$ sites on a
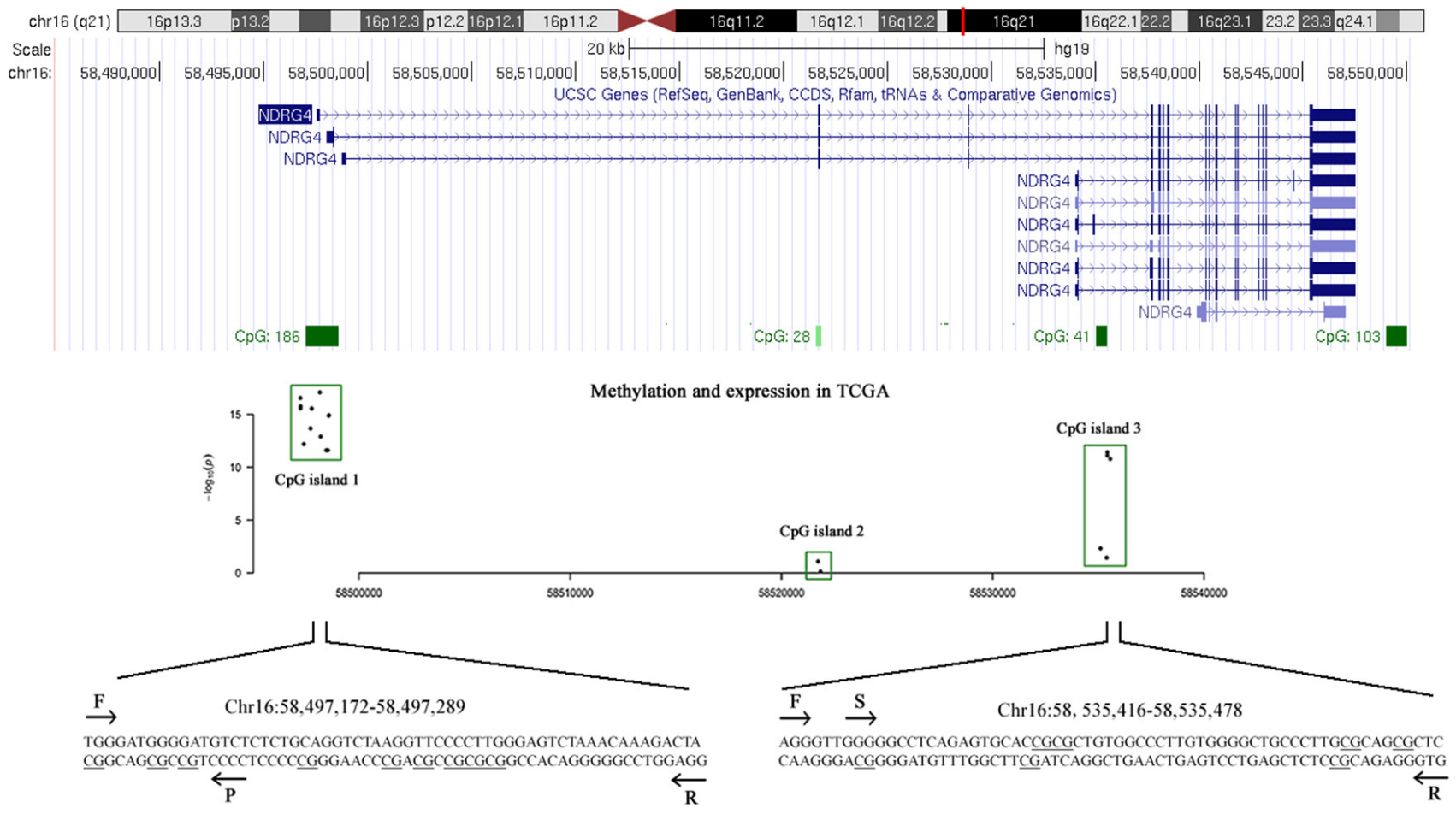

Figure 1: The tested CpG sites in NDRG4 promoter and gene body regions. A scatter plot describes the correlation between DNA methylation profiles (Illumina Human Methylation 450K) and gene expression profiles (IlluminaHiSeq_RNA-SeqV2) obtained from TCGA datasets. The $\mathrm{x}$-axis represents the genomic coordinates of $N D R G 4$ gene $\mathrm{CpG}$ sites, and the $\mathrm{y}$-axis represents the negative logarithm of the association $P$-value for each $\mathrm{CpG}$ site. F stands for forward primer; R stands for reverse primer; $\mathrm{S}$ stands for sequencing primer by pyrosequencing method; P stands for probe by MethyLight method. 
promoter CGI fragment (chr16:58,497,172-58,497,289) using MethyLight. We found in patients that the percent of methylated reference (PMR) of NDRG4 promoter was significantly increased in tumor tissues than paired adjacent normal tissues (medians with interquartile range, 1.68\% (0.00-7.81\%) versus $0.00 \%(0.00-0.01 \%), P<0.001$, Figure 2A). CpG sites test on gene body CGI fragment (chr16:58,535,416-58,535,478) was using bisulfite pyrosequencing. We also observed a hypermethylated NDRG4 gene body in tumors than matched adjacent normal tissues (mean \pm standard deviation, $19.87 \pm$ $11.88 \%$ versus $13.80 \pm 4.38 \%, P<0.001$, Figure $2 \mathrm{~B}$ ). Spearman correlation showed a moderately positive relationship between promoter methylation and gene body methylation ( $\mathrm{r}=0.286, P=0.002$, data not shown), suggesting an overall elevated methylation level in gastric cancer. This result was compatible with the correlation between average methylation levels of HM450K CpG probes at amplified promoter $(\operatorname{cg} 04190807, \operatorname{cg} 00687686$ and cg04942472) and those at amplified gene body (cg11640773 and $\operatorname{cg} 27102864)$ in TCGA data $(r=0.650$, $P<0.001$, data not shown). Meanwhile, Figure 2C and 2D showed NDRG4 methylation was a potential diagnostic biomarker of gastric cancer (promoter methylation: $65.5 \%$ for sensitivity and $77.3 \%$ for specificity; gene body methylation: $39.1 \%$ for sensitivity and $90.0 \%$ for specificity). The combined sensitivity and combined specificity were $51.8 \%$ and $85.5 \%$, respectively.

\section{Aberrant methylation with clinical phenotypes}

Two detection methods (MethyLight and pyrosequencing) were applied in the promoter and gene body regions, which yielded different data distributions of DNA methylation levels. Therefore, we used different cut-off values for subsequent analyses. In Table 1, a
A

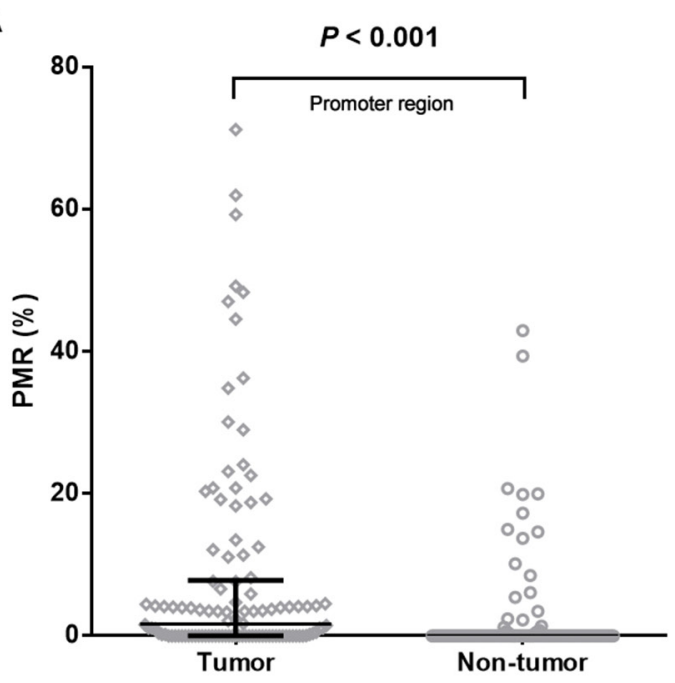

C

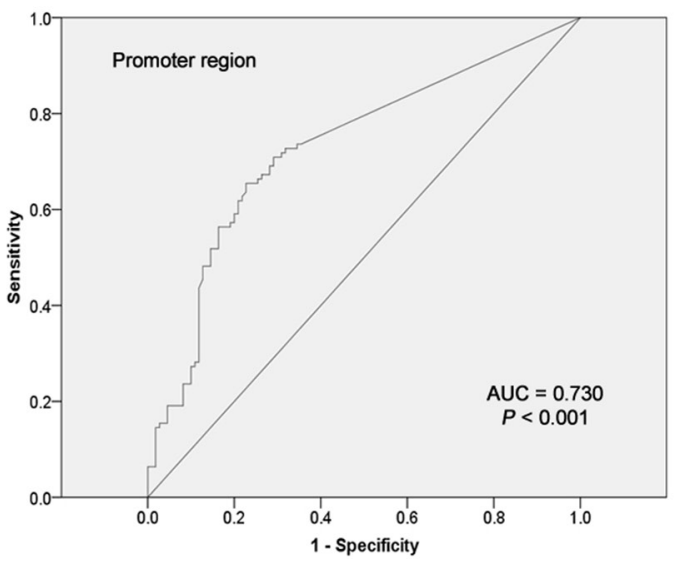

B

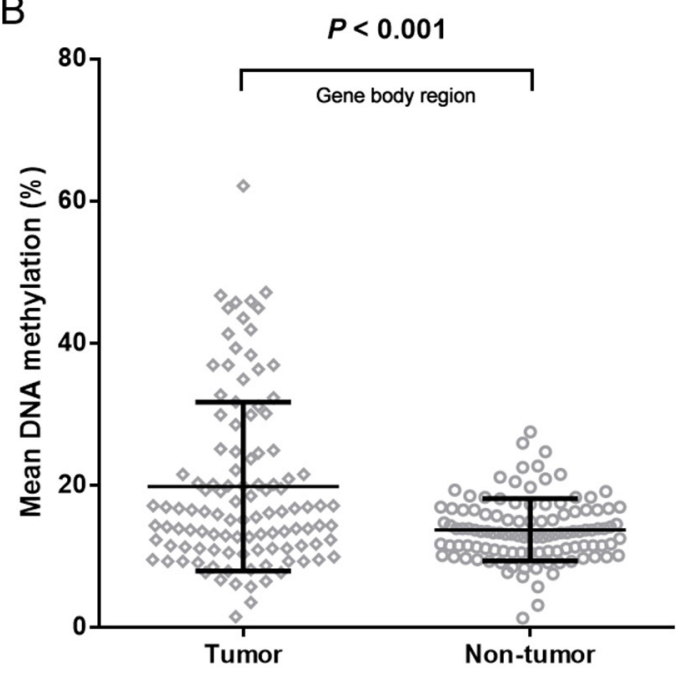

D

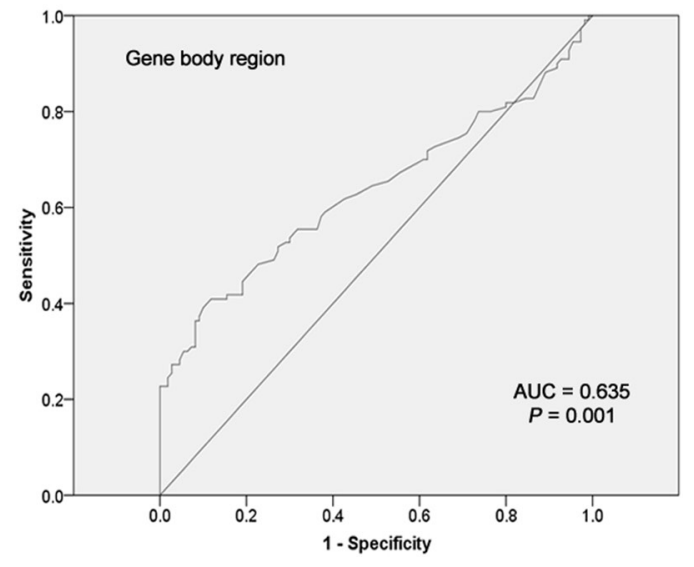

Figure 2: Analysis of NDRG4 gene methylation in gastric cancer patients. A. Data at promoter region are presented as medians (interquartile range). B. Data at gene body region are presented as means \pm standard deviation. C. ROC curve for NDRG4 promoter methylation with an AUC of 0.730. D. ROC curve for NDRG4 gene body methylation with an AUC of 0.635. 
Table 1: Association of NDRG4 promoter and body methylation with clinical characteristics of gastric cancer patients

\begin{tabular}{|c|c|c|c|c|c|c|c|}
\hline $\begin{array}{l}\text { Clinical } \\
\text { characteristics }\end{array}$ & Number & $\begin{array}{l}\text { NDRG4 } \\
\text { promoter } \\
\text { hypomethylation }^{a}\end{array}$ & $\begin{array}{l}\text { NDRG4 } \\
\text { promoter } \\
\text { hypermethylation }^{\text {a }}\end{array}$ & $P$ value $^{\mathrm{c}}$ & $\begin{array}{l}\text { NDRG4 } \\
\text { body } \\
\text { hypomethylation }^{\text {b }}\end{array}$ & $\begin{array}{l}\text { NDRG4 } \\
\text { body } \\
\text { hypermethylation }^{\mathrm{b}}\end{array}$ & $P$ value $^{\mathrm{c}}$ \\
\hline Total cases & 110 & 68 & 42 & & 70 & 40 & \\
\hline Gender & & & & 0.994 & & & 0.258 \\
\hline Male & 76 & 47 & 29 & & 51 & 25 & \\
\hline Female & 34 & 21 & 13 & & 19 & 15 & \\
\hline Age (years) & & & & 0.304 & & & $<0.001$ \\
\hline$<50$ & 33 & 18 & 15 & & 12 & 21 & \\
\hline$\geq 50$ & 77 & 50 & 27 & & 58 & 19 & \\
\hline Tumor location & & & & 0.402 & & & 0.210 \\
\hline Upper & 25 & 18 & 7 & & 19 & 6 & \\
\hline Middle & 25 & 16 & 9 & & 13 & 12 & \\
\hline Lower & 60 & 34 & 26 & & 38 & 22 & \\
\hline Tumor size & & & & 0.525 & & & 0.337 \\
\hline$<6 \mathrm{~cm}$ & 67 & 43 & 24 & & 45 & 22 & \\
\hline$\geq 6 \mathrm{~cm}$ & 43 & 25 & 18 & & 25 & 18 & \\
\hline Differentiation & & & & 0.243 & & & 0.004 \\
\hline $\begin{array}{l}\text { High and } \\
\text { medium }\end{array}$ & 47 & 32 & 15 & & 37 & 10 & \\
\hline $\begin{array}{l}\text { Low and } \\
\text { none }\end{array}$ & 63 & 36 & 27 & & 33 & 30 & \\
\hline $\begin{array}{l}\text { Lymph node } \\
\text { metastasis }\end{array}$ & & & & 0.240 & & & 0.307 \\
\hline Positive & 94 & 56 & 38 & & 58 & 36 & \\
\hline Negative & 16 & 12 & 4 & & 12 & 4 & \\
\hline TNM stage & & & & 0.058 & & & 0.517 \\
\hline $\mathrm{I}+\mathrm{II}$ & 17 & 14 & 3 & & 12 & 5 & \\
\hline III+ IV & 93 & 54 & 39 & & 58 & 35 & \\
\hline Borrmann type & & & & $0.304^{*}$ & & & $0.058^{*}$ \\
\hline $\mathrm{I}+\mathrm{II}$ & 5 & 2 & 3 & & 1 & 4 & \\
\hline III+ IV & 105 & 66 & 39 & & 69 & 36 & \\
\hline $\begin{array}{l}\text { Drinking } \\
\text { history }\end{array}$ & & & & 0.555 & & & 0.591 \\
\hline Yes & 28 & 16 & 12 & & 19 & 9 & \\
\hline No & 82 & 52 & 30 & & 51 & 31 & \\
\hline $\begin{array}{l}\text { Smoking } \\
\text { history }\end{array}$ & & & & 0.279 & & & 0.195 \\
\hline Yes & 30 & 21 & 9 & & 22 & 8 & \\
\hline No & 80 & 47 & 33 & & 48 & 32 & \\
\hline
\end{tabular}




\begin{tabular}{|c|c|c|c|c|c|c|c|}
\hline $\begin{array}{l}\text { Clinical } \\
\text { characteristics }\end{array}$ & Number & $\begin{array}{l}\text { NDRG4 } \\
\text { promoter } \\
\text { hypomethylation }^{a}\end{array}$ & $\begin{array}{l}\text { NDRG4 } \\
\text { promoter } \\
\text { hypermethylation }^{\mathrm{a}}\end{array}$ & $P$ value $^{\mathrm{c}}$ & $\begin{array}{l}\text { NDRG4 } \\
\text { body } \\
\text { hypomethylation }^{b}\end{array}$ & $\begin{array}{l}\text { NDRG4 } \\
\text { body } \\
\text { hypermethylation }^{\text {b }}\end{array}$ & $P$ value $^{\mathrm{c}}$ \\
\hline $\begin{array}{l}\text { Disease } \\
\text { recurrence }\end{array}$ & & & & 0.746 & & & 0.093 \\
\hline Yes & 20 & 13 & 7 & & 16 & 4 & \\
\hline No & 90 & 55 & 35 & & 54 & 36 & \\
\hline
\end{tabular}

Bold value indicates statistical significance. ${ }^{\mathrm{a}}$ Cutoff value of NDRG4 hypermethylation is set at $20 \% .{ }^{\mathrm{b}}$ Cutoff value of PMR is set at $4 \%$. ${ }^{\text {c }}$ Pearson $\chi^{2}$ test, unless otherwise noted. ${ }^{*}$ Fisher's exact test.

total of $42(38.18 \%)$ tumor tissues and 13 (11.82\%) nontumor tissues were defined as hypermethylated using the standard cutoff value of PMR is $4 \%[25-28](\mathrm{OR}=4.609$, $95 \% \mathrm{CI}=2.300-9.234, P<0.001)$. Referring to the cut-off value of gene body methylation rate, we used the mean methylation level of tumor tissues as described previously [29]. $40(36.36 \%)$ tumors and $9(8.18 \%)$ normal tissues were hypermethylated $(\mathrm{OR}=6.413,95 \% \mathrm{CI}=2.926$ 14.055, $P<0.001$ ).

Patients were divided into younger $(<=50$ years $)$ and older ( $>50$ years) according to a 4282 patientsbased retrospective study which described that earlyonset gastric cancer before age of 50 was associated with family history and needed to start screening earlier [30]. Our results showed that NDRG4 gene body were more frequently hypermethylated in the tumors of people aged younger than 50 years than those older than 50 years $(63.64 \%$ versus $24.68 \%, P<0.001$, Table 1$)$. Meanwhile, NDRG4 gene body hypermethylation was significantly found in lower differentiation than high/ medium differentiation $(47.62 \%$ versus $21.28 \%, P=$ 0.004). However, NDRG4 hypermethylation was not associated with other parameters, such as gender, tumor location, tumor size, lymph node metastasis, TNM stage, Borrmann type, drinking history, smoking history and disease recurrence $(P>0.05)$.

\section{Survival analysis}

In the current study, the 5-year overall survival (OS) rate of 110 gastric cancer patients was $25.10 \%$. As shown in Table 2, Kaplan-Meier survival analysis showed that six clinicopathological characteristics were significantly associated with OS, including age $(P=0.001)$, tumor size $(P=0.007)$, lymph node metastasis $(P=0.004)$, TNM stage $(P=0.001)$, disease recurrence $(P=0.009)$, and $N D R G 4$ promoter hypermethylation $(P=0.002$, Figure $3 \mathrm{~A})$. These potentially important factors in univariate analyses were included in multivariate analysis. After being adjusted in a Cox proportional hazard model, age at diagnosis was a strongly independent predictor for gastric cancer prognosis $(P=0.007)$. More importantly, $N D R G 4$ promoter hypermethylation was shown to be associated with poor $\mathrm{OS}$ of gastric cancer $(\mathrm{HR}=1.881,95 \% \mathrm{CI}=$ 1.107-3.218, $P=0.020$, Table 2). However, $N D R G 4$ gene body methylation was not shown to be associated with gastric cancer prognosis ( $P=0.504$, Figure 3B). In TCGA cohort of 357 gastric cancer patients, Cox regression analysis revealed an inconsistent result that patients with $N D R G 4$ hypermethylation had a better prognosis (promoter: $P=0.040$, Figure $3 \mathrm{C}$; gene body: $P=0.012$, Figure 3D).

\section{The correlation between promoter methylation and gene expression}

In order to provide a strong evidence for validating the negative regulation of promoter methylation on gene expression, we performed two parts in cell level. Firstly, we measured $N D R G 4$ promoter methylation levels in five human gastric cancer cell lines (MKN-74 from well differentiated adenocarcinoma; MKN-45, MGC803, BGC-823 and AGS, from poorly differentiated adenocarcinoma) and non cancerous gastric mucous cell (GES-1). The result showed that significantly higher NDRG4 promoter methylation levels in gastric cell lines were all observed compared to normal cell lines (fold change $=5.578-30.607$, all $P<0.05$, Figure 4A) . Meanwhile, NDRG4 mRNA expression was detected in MGC-803, AGS, BGC-823, and GES-1 cell lines using quantitative real-time PCR (qPCR). Compared with the NDRG4 mRNA level in GES-1 (set at 1), the relative expression levels of $N D R G 4$ in MGC-803, AGS and BGC823 were all decreased $(0.318 \pm 0.032,0.403 \pm 0.005$, $0.434 \pm 0.020$, respectively; Figure 4B). Secondly, with the data mining of Gene Expression Omnibus (GEO) database (accession number GSE15455), we have found a negative correlation between $N D R G 4$ promoter methylation and expression (Figure 4A and 4C).

Moreover, average methylation levels of $\mathrm{CpG}$ probes were inversely associated with gene mRNA expression in TCGA data (promoter: $\mathrm{r}=-0.411, P<$ 0.001 , Figure $5 \mathrm{~A}$; gene body: $\mathrm{r}=-0.347, P<0.001$, Figure $5 B)$. Subsequently, two dual-luciferase reporter vectors 
Table 2: Independent predictors of patients' overall survival by multivariate analysis

\begin{tabular}{|c|c|c|c|c|c|}
\hline $\begin{array}{l}\text { Clinical } \\
\text { characteristics }\end{array}$ & $\begin{array}{l}\text { Median OS } \\
\text { (months) }\end{array}$ & $\chi^{2}$ value & $\begin{array}{c}\text { Univariate } \\
P \text { value }\end{array}$ & $\begin{array}{c}\text { Hazard ratio } \\
(95 \% \mathrm{CI})\end{array}$ & $\begin{array}{c}\text { Multivariate } \\
P \text { value * }\end{array}$ \\
\hline \multicolumn{6}{|l|}{ Gender } \\
\hline Male / Female & $34 / 35$ & 0.060 & 0.806 & & \\
\hline \multicolumn{6}{|l|}{ Age (years) } \\
\hline$<50 / \geq 50$ & $\mathrm{NA} / 30$ & 11.994 & 0.001 & $2.933(1.343-6.406)$ & 0.007 \\
\hline \multicolumn{6}{|l|}{ Tumor location } \\
\hline $\begin{array}{l}\text { Upper / Middle / } \\
\text { Lower }\end{array}$ & $28 / 22 / 36$ & 5.651 & 0.059 & & \\
\hline \multicolumn{6}{|l|}{ Tumor size } \\
\hline$<6 \mathrm{~cm} / \geq 6 \mathrm{~cm}$ & $36 / 19$ & 7.267 & 0.007 & $1.464(0.857-2.503)$ & 0.163 \\
\hline \multicolumn{6}{|l|}{ Differentiation } \\
\hline $\begin{array}{l}\text { Low and none / } \\
\text { High and medium }\end{array}$ & $31 / 36$ & 1.235 & 0.266 & & \\
\hline \multicolumn{6}{|l|}{$\begin{array}{l}\text { Lymph node } \\
\text { metastasis }\end{array}$} \\
\hline Negative / Positive & $31 / \mathrm{NA}$ & 8.422 & 0.004 & 3.117 (0.695-13.987) & 0.138 \\
\hline \multicolumn{6}{|l|}{ TNM stage } \\
\hline I+II / III+IV & $\mathrm{NA} / 30$ & 11.972 & 0.001 & $2.793(0.598-13.049)$ & 0.192 \\
\hline \multicolumn{6}{|l|}{ Borrmann type } \\
\hline $\mathrm{I}+\mathrm{II} / \mathrm{III}+\mathrm{IV}$ & $\mathrm{NA} / 34$ & 1.231 & 0.267 & & \\
\hline \multicolumn{6}{|l|}{ Drinking history } \\
\hline No / Yes & $35 / 34$ & 0.020 & 0.887 & & \\
\hline \multicolumn{6}{|l|}{ Smoking history } \\
\hline No / Yes & $34 / 35$ & 1.486 & 0.223 & & \\
\hline \multicolumn{6}{|l|}{ Disease recurrence } \\
\hline No / Yes & $35 / 18$ & 6.753 & 0.009 & $1.388(0.764-2.524)$ & 0.282 \\
\hline$N D R G 4$ promoter & & 9.204 & 0.002 & $1.887(1.107-3.218)$ & 0.020 \\
\hline $\begin{array}{l}\text { Hypomethylation / } \\
\text { Hypermethylation }\end{array}$ & $36 / 23$ & & & & \\
\hline$N D R G 4$ body & & 0.446 & 0.504 & & \\
\hline $\begin{array}{l}\text { Hypomethylation / } \\
\text { Hypermethylation }\end{array}$ & $35 / 31$ & & & & \\
\hline
\end{tabular}

Bold value indicates statistical significance. * Potentially important factors in univariate analyses $(P<0.05)$ are included in multivariate analysis. Each former charactvbfferistic is set as the reference category for hazard ratio value. OS: overall survival; NA: not available for censored data.

containing tested promoter and gene body fragments were identified by enzyme digestion and DNA sequencing. The result showed a significantly higher activity of NDRG4 promoter specific region ( $-377 \mathrm{bp}$ to $+23 \mathrm{bp}$ ) but not gene body region when compared with pGL3 Basic (fold change $=3.702, P=0.007$, Figure $5 \mathrm{C}$ ).

\section{DISCUSSION}

Members of the NDRG family have been reported to be important to tumorigenesis and tumor progression in recent years [31]. The study of NDRG4 and cancer is gaining more and more attention, although discrepant 
results have been observed. Schilling et al. [32] have found that NDRG4 was elevated in glioblastoma compared to human cortex tissues and NDRG4 knockdown reduces the cell viability of glioblastoma cells. However, Ding et al. [18] have held the view that NDRG4 was downregulated at both $\mathrm{mRNA}$ and protein levels in glioblastoma tissues compared to normal brain tissues. Chu et al. [33] reported that NDRG4 may play its tumor suppressive role in carcinogenesis and progression through attenuation of PI3K-AKT activity in colorectal cancer. In contrast, Kotipatruni et al. [19] demonstrated that NDRG4 downregulation resulted in decreased cell proliferation, migration and invasion in aggressive meningiomas cell lines, revealing an oncogenic role in meningioma carcinogenesis. Therefore, we tend to explore the association of NDRG4 with gastric cancer in Chinese.

Previous NDRG4 methylation studies were mainly involved in colorectal cancer [20, 21, 34-36] and pancreatic cancer $[37,38]$. Significantly increased $N D R G 4$ promoter methylation levels were observed in colorectal cancer tissues compared to paired non-tumor tissues [34, 35]. Meanwhile, NDRG4 methylation might serve as an early detective biomarker in pancreatic cancer $[37,38]$. In the present study, we reported for the first time that $N D R G 4$ promoter hypermethylation served as a predictive biomarker in gastric cancer in spite of moderate sensitivity and specificity. Currently, the gastroscopic biopsy is the gold standard for diagnosis of gastric cancer [39]. Since
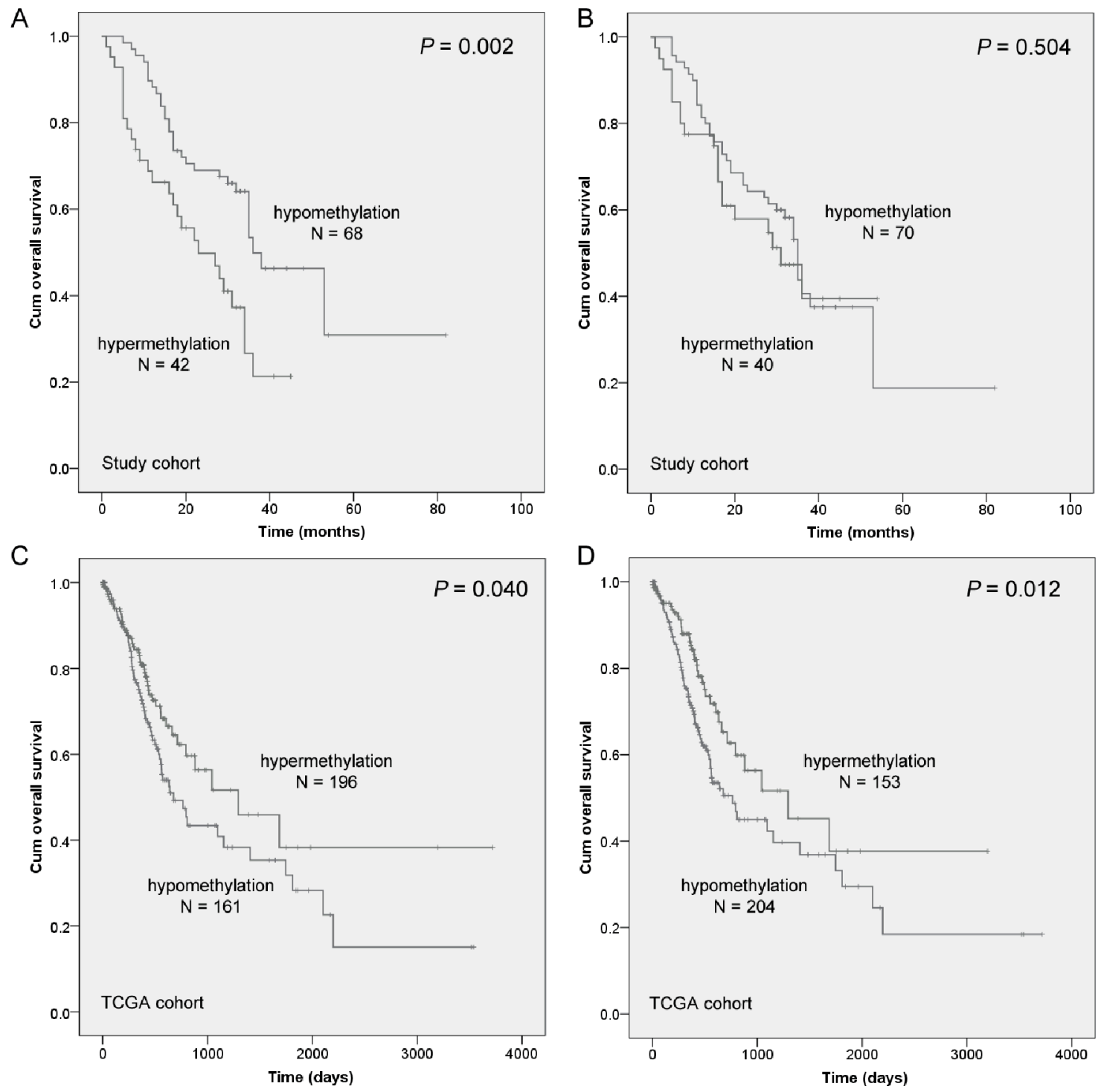

Figure 3: The association between NDRG4 methylation level and the prognosis of gastric cancer patients. Prognostic role of A. NDRG4 promoter methylation and B. gene body methylation levels from our cohort in Kaplan-Meier curves. A cutoff value of PMR is set at $4 \%$. A cutoff value of gene body methylation rate is set at $20 \%$. Prognostic role of C. NDRG4 promoter methylation and D. gene body methylation levels from TCGA cohort in Kaplan-Meier curves. A cutoff values is set at the median of methylation level. 
the approach is limited for its invasiveness and the results are always influenced by the operator's experience, strategies for gastric cancer biomarker discovery tend to be urgent. Serum carcinoembryonic antigen (CEA), cancer antigen 19-9 (CA19-9), cancer antigen 72-4 (CA724) and pepsinogen are conventional cancer biomarkers assessed in gastric cancer [40, 41]. Liang et al. [40] has reported that the sensitivity of CEA, CA19-9, and CA724 in the diagnosis of gastric cancer was 20.1-27.6\% individually and $48.2 \%$ jointly in a Chinese population, which suggested a lower diagnostic ability compared with our study. Serum pepsinogen detection in a metaanalysis generated an AUC of 0.76 [42], which was compatible with the AUC of 0.73 of NDRG4 promoter hypermethylation in gastric cancer tissues. For one thing, DNA methylation as a biomarker was more effective in the serum than that in tissues among gastric cancer patients [43]; therefore, NDRG4 methylation might have a higher diagnostic value in serum detection. For another, these gastric cancer-associated serum markers are considered to be the most frequently present in the late stage. Since DNA methylation could be detected beginning in the early stages of gastric cancer [44], it provided an easy and quick method for gastric cancer screening. In addition, assessment of the same biomarker turned to be different diagnostic abilities in high- and low-incidence regions [45]. Therefore, $N D R G 4$ promoter hypermethylation could exert higher potential in those high risk areas. Specimens tested in the current study were paired and obtained from the same patient, and thus we could not make a model to test the combined ROC curve. It is a complex regulatory network underlying gastric cancer. Noteworthy, it could improve the predicted efficacy if we made a suitable multivariate model by including clinical information or other important biomarkers.

Due to the limited materials, we didn't have matched gene expression of NDRG4 in tissues. Interestingly, we took advantage of cell lines and public databases and discovered a moderately inverse methylation-expression correlation in gastric cancer. Meanwhile, dual-luciferase
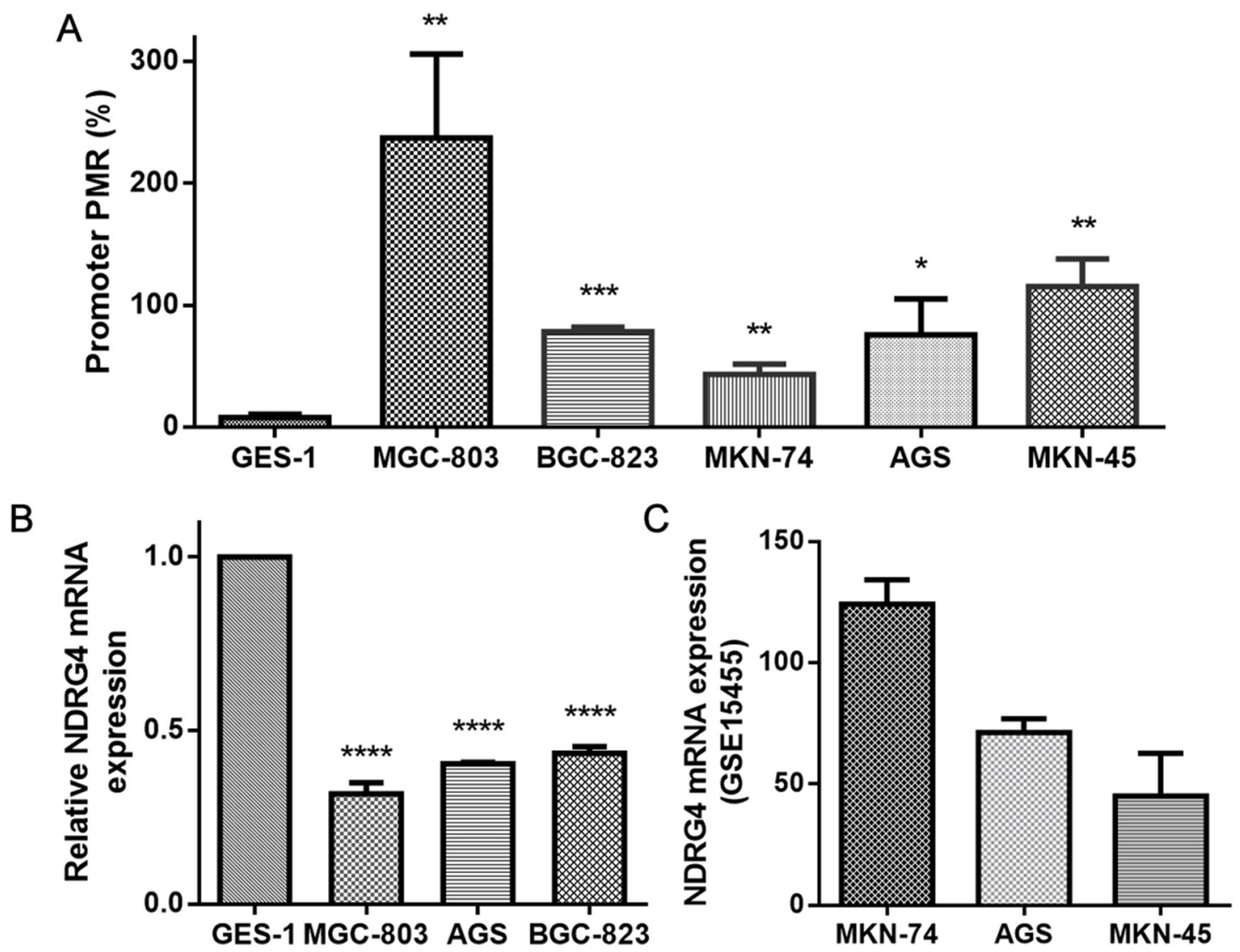

Figure 4: The evaluation of DNA methylation and gene expression in cell lines. A. $N D R G 4$ promoter methylation levels in GES-1, MGC-803, BGC-823, MKN-74, AGS and MKN-45 cell lines. Each reaction was performed in triplicate. ${ }^{*} P<0.05, * * P<0.01$, *** $P<0.001$, each gastric cancer cell line versus GES-1, statistical analysis was done using independent sample t test. B. Relative $N D R G 4$ mRNA expression in GES-1, MGC-803, BGC-823 and AGS cell lines. Each reaction was performed in triplicate. $* * * * P<0.0001$, each gastric cancer cell line versus GES-1 (set at 1), statistical analysis was done using independent sample t test. C. The mRNA expression of MKN-74, AGS and MKN-45 was obtained from GEO database (accession number GSE15455). 
reporter assay has suggested that $N D R G 4$ promoter specific region $(-377 b p$ to $+23 b p)$ contained a potential regulatory element. According to the study of Hapgood et al. [46], we have found that the 5'-UTR and transcription start site 200 (TSS200) regions of NDRG4 gene contains two GC-box elements (CGCCCCCGC and GCGGGGGCG), but lacks TATA- and CCAAT-box elements. The corresponding GC box-binding proteins are Zif268 [47] and NGFI-C [48], which exert positive effects on gene transcription. Since the function of GC-rich DNA is not linked to a particular cellular process or mechanism of regulation [46, 49], further relationship between NDRG4 methylation and other cis-regulatory elements in gastric carcinogenesis is needed to be explored. Previous study suggested that $\mathrm{CpG}$ sites hypermethylation in the first intron of tumor suppressor gene was significantly associated with an increased risk of colorectal cancer, and the demethylation of $\mathrm{CpG}$ sites could restore gene expression [50]. Although several studies have investigated the mechanism of gene body methylation on gene expression [51-53], the function of gene body methylation is largely unknown. DNA methylation on gene body was shown to positively or negatively regulate gene expression [54, 55]. Our findings showed that a much higher hypermethylation rate of NDRG4 gene body in tumor tissues than their adjacent tissues. Therefore, we speculated that $N D R G 4$ overall hypermethylation at promoter and gene body CGI could contribute to the risk of gastric cancer through its regulation of gene expression.

Our results observed that $N D R G 4$ body methylation was shown to be associated with age and differentiation. Age is a well known risk factor in the diagnosis and
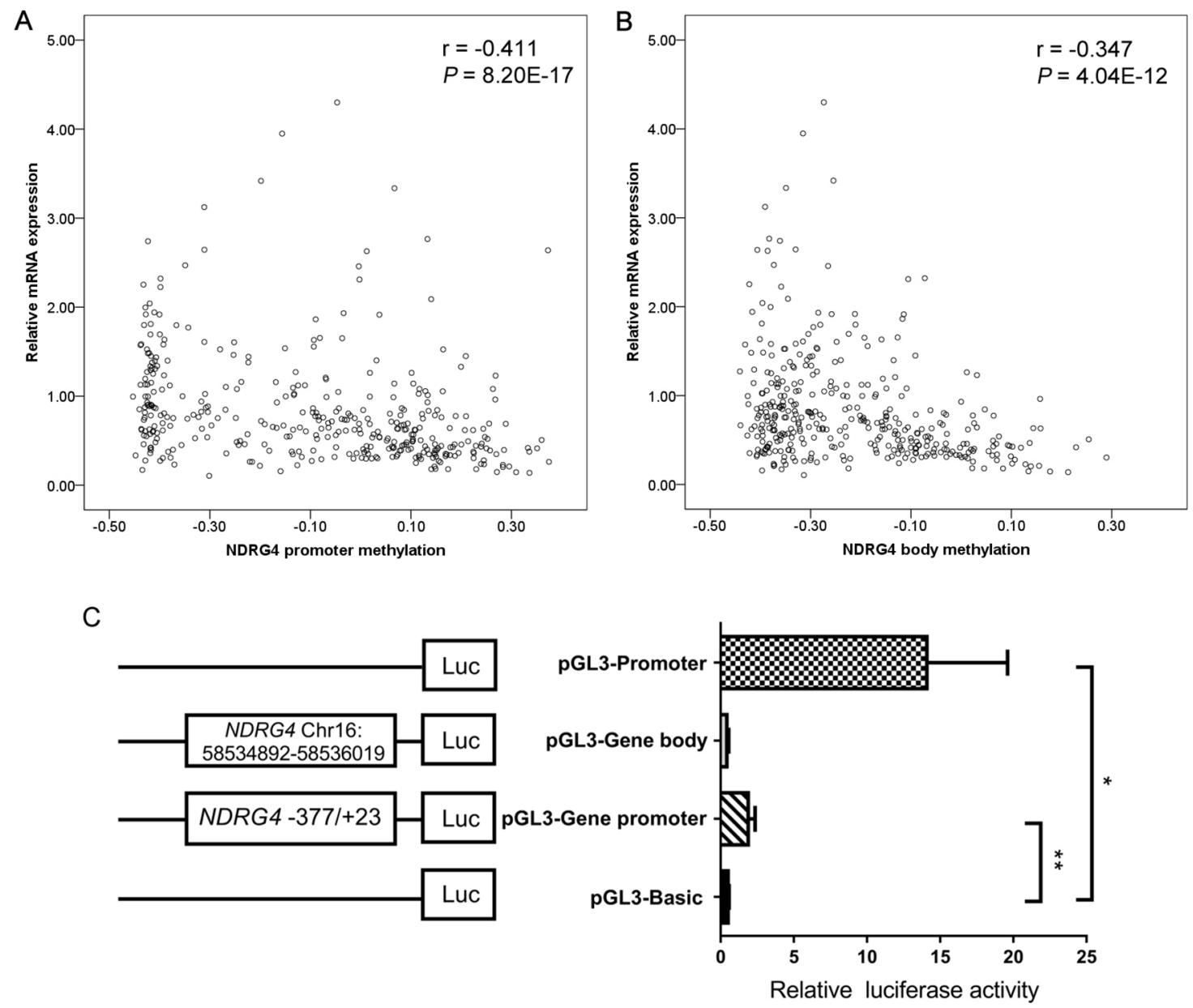

Figure 5: The functional role of NDRG4 in gastric cancer. A. Correlation between $N D R G 4$ promoter average methylation (cg04190807, cg00687686, cg04942472) and gene expression in 377 gastric adenocarcinoma patients from the TCGA data portal. B. NDRG4 gene body average methylation (cg11640773, cg27102864) and gene expression in 377 gastric adenocarcinoma patients from the TCGA data portal. C. Dual-luciferase reporter assay in HEK-293T cell line. The pGL3 Basic and Promoter vectors are used as negative and positive control respectively. Relative luciferase activity is performed in triplicates. Bars represent the means \pm standard deviation of three independent experiments. * $P<0.05$, pGL3 Promoter vector versus pGL3 Basic vector; ** $P<0.01$, pGL3-NDRG4 promoter vector $(-377 b p$ to $+23 b p)$ versus $p G L 3$ Basic vector. 
prognosis of gastric cancer $[30,56]$. We found that the degree of methylation difference between tumor and non-tumor tissues was negatively correlated with aging, providing a clue to elaborate the epigenetics mechanism of aberrant DNA methylation in gastric cancer during aging. $N D R G 4$ body hypermethylation may play an important role in gastric carcinogenesis in the younger patients. Screening for NDRG4 body hypermethylation might have clinical significance for the evaluation of younger patients with gastric cancer. In addition, those poorly differentiated tissues were inclined to accompany the NDRG4 body methylation changes during gastric cancer progression, suggesting the potential to distinguish different stages of differentiation.

Although no significance was found in NDRG4 promoter methylation with clinical characteristics, NDRG4 hypermethylation was shown as a poor prognostic biomarker in Chinese gastric patients but as an improved prognostic biomarker in TCGA data. Almost all gastric cancers are adenocarcinomas, and thus we speculated this discrepancy may be due to different ethnicities, therapies, and methylation detection methods. Positive NDRG4 staining was an independent predictor of favorable survival in a cohort including 272 Chinese colorectal cancer (CRC) patients [33]; however, we could not find the support evidence from $174 \mathrm{CRC}$ patients in TCGA4U [57], a web-based platform using TCGA datasets $(\mathrm{P}>0.05$, data not shown). Moreover, our previous work has showed that different ethnic groups existed diverse effects of gene methylation [58]. Taking the prognosis studies of malignant glioma for instance, we have found that $M G M T$ promoter methylation was associated with worse OS among Asians [59], whereas it was associated with longer OS among Caucasians [60]. In current study, 377 TCGA gastric patients are from Europe (100 samples), North and South America (128 samples), Asia (18 samples), and unknown region (131 samples). Therefore, ethnicity-based genetic heterogeneity should be considerable in the prognosis prediction. Further validation with larger sample size in other ethnic population is required. Different treatments always affect the outcomes of patients. Multiple agents are active in the treatment of gastric cancer, including fluoropyrimidines, platinum agents, anthracyclines, taxanes, and irinotecan [61]. It was difficult to determine whether the survival differences were caused by inherent prognostic differences or were a result of a treatment interaction, or both. In a study of a different design, Mitsuno et al. reported that patients with p16 methylation gained longer survival from chemotherapy, while those without methylation did not [62]. Since both TCGA data and our study cohort lacked sufficient treatment information, much further work is required to confirm our findings. Additionally, TCGA data are based on the high throughput sequencing method, and genome-scale methylation assessment alone was unlikely to inform patient outcome for oral tongue squamous cell carcinoma [63]. Therefore, it may be a shortcoming for drawing a prognostic conclusion study only relating to the HM450K platform itself.

Tumorigenesis is often associated with functional genetic variants, such as copy number alterations and loss of heterozygosity [64]. In NCBI dbSNP database, NDRG4 has 356 indel mutations, 3059 single nucleotide polymorphisms (SNPs) and 6 multiple nucleotide polymorphisms (MNPs). Among these variations, four SNPs (rs40186, rs246192, rs11076243 and rs11862356) have been cited in previous studies [65-68]. However, the research of NDRG4 variants in human cancers is scarce. A recent exome sequencing study [69] has identified that c.511G $>$ C (p.Val171Leu), a novel NDRG4 homozygous variant, is associated with the autosomal recessive form of infantile myofibromatosis, showing that $N D R G 4$ variations may play an important role in benign tumor. Future recent research on the interaction of genetic polymorphisms and epigenetic marks on NDRG4 gene might be useful to elaborate the role of this gene in gastric cancer risk.

In conclusion, our findings suggested that NDRG4 $\mathrm{CpG}$ island hypermethylation could be a potential biomarker for diagnosis of gastric cancer. Meanwhile, $N D R G 4$ promoter hypermethylation was identified as an independent prognostic factor for survival outcomes in Chinese gastric cancer patients, and it exerted a tumor suppressive role in carcinogenesis and progression through attenuation of $N D R G 4$ expression.

\section{MATERIALS AND METHODS}

\section{Tumor samples and TCGA data source}

Tumors and their paired adjacent tissues came from 110 gastric cancer patients diagnosed between January 2008 and February 2015 at the Zhejiang Province Cancer Hospital, China. All the patients were histologically verified with gastric adenocarcinoma before chemotherapy and radiotherapy. The OS was defined as the date of primary surgery to the date of death or the date of last follow-up [70]. All the specimens were freshly obtained and stored at $-80^{\circ} \mathrm{C}$. All of the experiments were approved by the Ethical Committees of the above mentioned hospital, and methods have been carried out in accordance with approved guidelines. All the patients had signed the informed consent forms.

For TCGA cohort, DNA methylation profiles (Illumina Human Methylation 450K, HM450K), gene expression profiles (IlluminaHiSeq_RNA-SeqV2) and clinical data generated from 377 stomach adenocarcinoma patients were available from the website of Cancer Genomics Browser of University of California Santa Cruz (UCSC) (https://genome-cancer.ucsc.edu/). Ethnic groups consist of those from Europe (100 samples), North and South Americas (128 samples), Asia (18 samples) and unknown region (131 samples). 


\section{Cell culture}

A non-cancerous gastric mucous cell (GES-1), five human gastric cancer cell lines [a well differentiated adenocarcinoma cell line (MKN-74) and four poorly differentiated adenocarcinoma (MKN-45, MGC-803, BGC-823 and AGS)], and the human embryonic kidney HEK293T cell line were obtained from the cell bank of Chinese academy of sciences (Shanghai, China). All of them were cultured at $37^{\circ} \mathrm{C}$ in high-glucose Dulbecco's modified Eagle's medium (DMEM, HyClone, Logan, Utah) supplemented with $10 \%$ fetal bovine serum (FBS, TransGen Biotech, Beijing, China).

\section{DNA isolation, bisulfite conversion, MethyLight method and pyrosequencing}

Genomic DNA was extracted by the QIAamp DNA Mini Kit (Qiagen $\mathrm{GmbH}$, Hilden, Germany) according to the manufacturer's instruction. DNA concentrations measure and bisulfite conversation of genomic were as previously shown [71].

MethyLight was used to measure the gene promoter methylation level in cell lines and all participants. It was performed in a total volume of $15 \mu \mathrm{L}$ containing $7.5 \mu \mathrm{L}$ $2 \times$ HotTaq Master Mix (QuanRen Biotech, Shanghai, China), $0.75 \mu \mathrm{L}$ forward and reverse primers $(5 \mu \mathrm{M}), 0.75$ $\mu \mathrm{L}$ Taqman probe $(2 \mu \mathrm{M}), 3.75 \mu \mathrm{L}$ nuclease-free water and $1.5 \mu \mathrm{L}$ bisulphite-converted DNA. Control reference gene $A C T B$ was amplified in parallel to normalize DNA input. Primer and probe sequences were listed in Table 3. MethyLight was performed on LightCycler 480 (Roche, Basel, Switzerland) under the following condition: $95^{\circ} \mathrm{C}$ for $10 \mathrm{~min}$, followed by 45 cycles of $95^{\circ} \mathrm{C}$ for $15 \mathrm{~s}$ and $60{ }^{\circ} \mathrm{C}$ for $45 \mathrm{~s}$. EpiTect methylated control DNA (Qiagen, Hilden, Germany) was used as a positive control. Water without DNA served as a control for contamination and primer dimer in each assay. Each MethyLight reaction was performed in duplicate, and PMR values were used to quantify the methylation level of each sample [72].

Pyrosequencing was applied to measure the gene body methylation levels in tissues. The details of pyrosequencing procedures were as previously shown [73]. Primer sequences and PCR conditions were listed in Table 3. Average methylation levels for NDRG4 gene body were calculated for the five $\mathrm{CpG}$ sites included in the assay.

\section{RNA extraction and QPCR method}

Total RNA was isolated from MGC-803, AGS, BGC-823, and GES-1 cell lines by Qiagen RNeasy Mini kit (Qiagen GmbH, Hilden, Germany). Reverse transcription-PCR was performed with $2 \mu \mathrm{g}$ of isolated total RNA and synthesized to cDNA in a $20 \mu \mathrm{l}$ reaction system using reverse transcriptase (Promega, Wisconsin, USA) with oligo-dT primers according to the manufacturer's instructions. QPCR to quantify $N D R G 4$ mRNA level was performed by SYBR Green master mix (Roche, Basel, Switzerland). The PCR system followed the same condition of MethyLight method mentioned above. Cyclophilin A was used as a reference gene for normalization. Primers were listed in Table 3. Gene expression levels were calculated using the $\Delta \mathrm{Ct}$ (delta cycle threshold) method: $\Delta \mathrm{Ct}=$ mean value $\mathrm{Ct}$ (mRNA reference) - mean value $\mathrm{Ct}$ (mRNA of interest). The relative mRNA expression of NDRG4 gene corresponded to the value $2^{\Delta \mathrm{Ct}}$.

\section{Construction of recombinant plasmids}

The fragment of $N D R G 4$ promoter $(-377 \mathrm{bp}$ to $+23 \mathrm{bp}$ ) was chemically synthesized and the fragment of gene body was amplified with forward primer 5'-CTTA CGCGTGCTAGCCCGTGGGGGAAGGCAACGCT-3' and reverse primer 5'-CGCAGATCTCGAGCCCCCT GCCAGGTGCCAGTCTC-3'. The amplified promoter DNA fragment was digested with XhoI and NheI, and the amplified gene body fragment was digested with Mlul and BgIII (New England Biolabs, Ipswich, MA). After being purified by Cycle Pure Kit (Omega, Norcross, GA, USA), the target fragment was cloned to pGL3 Basic vector (Promega, Madison city, WI, USA) by DNA Ligation Kit (Takara, Japan).

\section{Plasmids transfection and luciferase reporter assay}

Cells are prepared in 96-well plates and the details of plasmids transfection are as described previously [74]. After 18-72h of HEK293T cells transfection, luciferase activity is determined with the dual luciferase reporter assay system (Dual-Luciferase ${ }^{\circledR}$ Reporter Assay Systems, Promega, Madison city, WI, USA). Renilla and firefly luciferase activities were measured by SpectraMax 190 (Molecular Devices, Sunnyvale, USA).

\section{Statistical analysis}

All the statistical analyses were conducted with SPSS 18.0 software (SPSS Inc, Chicago, IL, USA) and R 3.1.2 software. Pearson $\chi^{2}$ test and Fisher's exact test were used to evaluate the association of the NDRG4 methylation with the clinical characteristics. Wilcoxon matched pairs test and paired sample t-test were applied for the comparisons of NDRG4 methylation between cancer tissues and their adjacent tissues. Spearman rank test was used to compute the correlation between NDRG4 methylation and gene expression. Kaplan-Meier method and log-rank test were applied to the data of the gastric cancer patients classified into two groups according to the NDRG4 methylation status. Cox proportional hazard model was fitted with calculating hazard ratio (HR) and the corresponding 95\% confidence interval (95\% CI). 


\begin{tabular}{llcc}
\hline & Primer sequence (5'-3') & $\begin{array}{c}\text { Amplicon } \\
\text { length (bp) }\end{array}$ & $\begin{array}{c}\text { Annealing temp. } \\
\left({ }^{\circ} \mathbf{C}\right)\end{array}$ \\
\hline Gene body-F & AGGGTTGGGGGTTTTAGA & & \\
Gene body-R & [Biotin]- & 128 & 55.4 \\
Gene body-S & CACCCTCTACCAAAAACTCAAAACTCAATT & & \\
Promoter-F & GGGGTTTTAGAGTGTAT & & \\
Promoter-R & TGGGATGGGGATGTTTTTGT & 60 \\
Promoter-P & CCTCCAAACCCCCTATAACC & 118 & \\
ACTB-F & [6FAM]-AAAACGACGCTACCGTAATCTTTA- & & \\
ACTB-R & [BHQ1] & & \\
ACTB-P & TGGTGATGGAGGAGGTTTAGTAAGT & & \\
NDRG4 mRNA-F & AACCAATAAAACCTACTCCTCCCTTAA & 133 \\
NDRG4 mRNA-R & [6FAM]- & & \\
Cyclophilin $A-\mathrm{F}$ & ACCACCACCCAACACACAATAACAAACACA- & & \\
Cyclophilin $A-\mathrm{R}$ & GGCCTTCTGCATGTAGTGATCCG & GGTGATCTCCTGCATGTCCTCG & 60 \\
\hline
\end{tabular}

F stands for forward primer; R stands for reverse primer; $\mathrm{S}$ stands for sequencing primer by pyrosequencing method; $\mathrm{P}$ stands for probe by MethyLight method.

Receiver operating characteristic (ROC) analysis was used to compare the sensitivity and specificity by the parameters. The firefly luciferase activity was normalized to the renilla luciferase activity, and values were presented as means \pm standard deviation from three single experiments. $P<0.05$ was considered to be statistically significant.

\section{Abbreviations}

NDRG4, N-Myc downstream regulated gene 4; TCGA, The Cancer Genome Atlas; TNM, tumor node metastasis; CGI, cytosine-phosphate-guanine island; PMR, the percent of methylated reference; OS, overall survival; qPCR, quantitative real-time PCR; GEO, Gene Expression Omnibus; SNP, single nucleotide polymorphism; MNP, multiple nucleotide polymorphism; $\mathrm{HR}$, hazard ratio; CI: confidence interval; ROC, receiver operating characteristic; AUC, area under the curve.

\section{ACKNOWLEDGMENTS}

We would like to thank the TCGA and GEO databases for their open access.
The research was supported by the grants from the National Natural Science Foundation of China (81371469), Zhejiang Provincial Natural Science Foundation (LY14H160008), Ningbo City Medical Science and Technology projects (2014A20), and K. C. Wong Magna Fund in Ningbo University.

\section{CONFLICTS OF INTEREST}

The authors declare no conflicts of interest.

\section{Author contributions}

$\mathrm{XC}, \mathrm{SD}$ and $\mathrm{JY}$ conceived of and designed the study. YY, JL, GL, BL and CL performed the experiments. $\mathrm{XC}, \mathrm{QX}$ and $\mathrm{YX}$ performed the analyses. $\mathrm{XC}, \mathrm{YC}$ and LJ prepared all figures and tables. $\mathrm{XC}$ wrote the main manuscript. All the authors reviewed the manuscript.

\section{REFERENCES}

1. Liang H, Kim YH. Identifying molecular drivers of gastric cancer through next-generation sequencing. Cancer letters. 2013; 340:241-246. 
2. Chen W, Zheng R, Baade PD, Zhang S, Zeng H, Bray F, Jemal A, Yu XQ, He J. Cancer statistics in China, 2015. CA. 2016; 66:115-132.

3. Cheng XJ, Lin JC, Tu SP. Etiology and Prevention of Gastric Cancer. Gastrointestinal tumors. 2016; 3:25-36.

4. Tahara T, Arisawa T. DNA methylation as a molecular biomarker in gastric cancer. Epigenomics. 2015; 7:475-486.

5. Thrumurthy SG, Chaudry MA, Chau I, Allum W. Does surgery have a role in managing incurable gastric cancer? Nature reviews Clinical oncology. 2015.

6. Nakamura J, Tanaka T, Kitajima Y, Noshiro H, Miyazaki $\mathrm{K}$. Methylation-mediated gene silencing as biomarkers of gastric cancer: a review. World journal of gastroenterology. 2014; 20:11991-12006.

7. Lin X, Zhao Y, Song WM, Zhang B. Molecular classification and prediction in gastric cancer. Computational and structural biotechnology journal. 2015; 13:448-458.

8. Kanda M, Kobayashi D, Tanaka C, Iwata N, Yamada S, Fujii T, Nakayama G, Sugimoto H, Koike M, Nomoto S, Murotani K, Fujiwara M, Kodera Y. Adverse prognostic impact of perioperative allogeneic transfusion on patients with stage II/III gastric cancer. Gastric cancer. 2015.

9. Cho JY. Molecular diagnosis for personalized target therapy in gastric cancer. Journal of gastric cancer. 2013; 13:129-135.

10. Capuano V, Souied EH, Semoun O, Cavallero E, Querques G. [Multicolor imaging in a case of acute macular neuroretinopathy]. Journal francais d'ophtalmologie. 2015; 38:e19-21.

11. Zheng YZ, Wen J, Cao X, Yang H, Luo KJ, Liu QW, Huang QY, Chen JY, Fu JH. Decreased mRNA expression of transcription factor forkhead box F2 is an indicator of poor prognosis in patients with resected esophageal squamous cell carcinoma. Molecular and clinical oncology. 2015; 3:713-719.

12. Ahrens TD, Werner M, Lassmann S. Epigenetics in esophageal cancers. Cell and tissue research. 2014; 356:643-655.

13. Nishizawa T, Suzuki H. Gastric Carcinogenesis and Underlying Molecular Mechanisms: and Novel Targeted Therapy. BioMed research international. 2015; 2015:794378.

14. Kanda M, Kodera Y. Recent advances in the molecular diagnostics of gastric cancer. World journal of gastroenterology. 2015; 21:9838-9852.

15. Calcagno DQ, Gigek CO, Chen ES, Burbano RR, Smith Mde A. DNA and histone methylation in gastric carcinogenesis. World journal of gastroenterology. 2013; 19:1182-1192.

16. Li Y, Liang J, Hou P. Hypermethylation in gastric cancer. Clinica chimica acta. 2015; 448:124-132.

17. Kotipatruni RP, Ferraro DJ, Ren X, Vanderwaal RP, Thotala DK, Hallahan DE, Jaboin JJ. NDRG4, the N-Myc downstream regulated gene, is important for cell survival, tumor invasion and angiogenesis in meningiomas. Integr Biol (Camb). 2012; 4:1185-1197.

18. Ding W, Zhang J, Yoon JG, Shi D, Foltz G, Lin B. NDRG4 is downregulated in glioblastoma and inhibits cell proliferation. OMICS. 2012; 16:263-267.

19. Kotipatruni RP, Ren X, Thotala D, Jaboin JJ. NDRG4 is a novel oncogenic protein and p53 associated regulator of apoptosis in malignant meningioma cells. Oncotarget. 2015; 6:17594-17604. doi: 10.18632/oncotarget.4009.

20. Xiao W, Zhao H, Dong W, Li Q, Zhu J, Li G, Zhang S, Ye M. Quantitative detection of methylated NDRG4 gene as a candidate biomarker for diagnosis of colorectal cancer. Oncology letters. 2015; 9:1383-1387.

21. Melotte V, Lentjes MH, van den Bosch SM, Hellebrekers DM, de Hoon JP, Wouters KA, Daenen KL, PartounsHendriks IE, Stessels F, Louwagie J, Smits KM, Weijenberg MP, Sanduleanu S, Khalid-de Bakker CA, Oort FA, Meijer GA, et al. N-Myc downstream-regulated gene 4 (NDRG4): a candidate tumor suppressor gene and potential biomarker for colorectal cancer. J Natl Cancer Inst. 2009; 101:916-927.

22. Skiriute D, Steponaitis G, Vaitkiene P, Mikuciunas M, Skauminas K, Tamasauskas A, Kazlauskas A. Glioma Malignancy-Dependent NDRG2 Gene Methylation and Downregulation Correlates with Poor Patient Outcome. Journal of Cancer. 2014; 5:446-456.

23. Qu X, Zhai Y, Wei H, Zhang C, Xing G, Yu Y, He F. Characterization and expression of three novel differentiation-related genes belong to the human NDRG gene family. Molecular and cellular biochemistry. 2002; 229:35-44.

24. Rand K, Qu W, Ho T, Clark SJ, Molloy P. Conversionspecific detection of DNA methylation using real-time polymerase chain reaction (ConLight-MSP) to avoid false positives. Methods. 2002; 27:114-120.

25. Eads CA, Lord RV, Kurumboor SK, Wickramasinghe K, Skinner ML, Long TI, Peters JH, DeMeester TR, Danenberg KD, Danenberg PV, Laird PW, Skinner KA. Fields of aberrant $\mathrm{CpG}$ island hypermethylation in Barrett's esophagus and associated adenocarcinoma. Cancer research. 2000; 60:5021-5026.

26. Eads CA, Lord RV, Wickramasinghe K, Long TI, Kurumboor SK, Bernstein L, Peters JH, DeMeester SR, DeMeester TR, Skinner KA, Laird PW. Epigenetic patterns in the progression of esophageal adenocarcinoma. Cancer research. 2001; 61:3410-3418.

27. Ogino S, Kawasaki T, Brahmandam M, Cantor M, Kirkner GJ, Spiegelman D, Makrigiorgos GM, Weisenberger DJ, Laird PW, Loda M, Fuchs CS. Precision and performance characteristics of bisulfite conversion and real-time PCR (MethyLight) for quantitative DNA methylation analysis. The Journal of molecular diagnostics. 2006; 8:209-217.

28. Dong X, He H, Zhang W, Yu D, Wang X, Chen Y. Combination of serum RASSF1A methylation and AFP is a promising non-invasive biomarker for HCC patient 
with chronic HBV infection. Diagnostic pathology. 2015; 10:133.

29. Wang ZR, Wei JH, Zhou JC, Haddad A, Zhao LY, Kapur P, Wu KJ, Wang B, Yu YH, Liao B, He DL, Chen W, Margulis V, Hsieh JT, Luo JH. Validation of DAB2IP methylation and its relative significance in predicting outcome in renal cell carcinoma. Oncotarget. 2016; 7:31508-31519. doi: 10.18632/oncotarget.8971.

30. Kwak HW, Choi IJ, Kim CG, Lee JY, Cho SJ, Eom BW, Yoon HM, Joo J, Ryu KW, Kim YW. Individual having a parent with early-onset gastric cancer may need screening at younger age. World journal of gastroenterology. 2015; 21:4592-4598.

31. Yang X, An L, Li X. NDRG3 and NDRG4, two novel tumor-related genes. Biomed Pharmacother. 2013; 67:681-684.

32. Schilling SH, Hjelmeland AB, Radiloff DR, Liu IM, Wakeman TP, Fielhauer JR, Foster EH, Lathia JD, Rich JN, Wang XF, Datto MB. NDRG4 is required for cell cycle progression and survival in glioblastoma cells. The Journal of biological chemistry. 2009; 284:25160-25169.

33. Chu D, Zhang Z, Zhou Y, Li Y, Zhu S, Zhang J, Zhao Q, Ji G, Wang W, Zheng J. NDRG4, a novel candidate tumor suppressor, is a predictor of overall survival of colorectal cancer patients. Oncotarget. 2015; 6:7584-7596. doi: 10.18632/oncotarget.3170.

34. Imperiale $\mathrm{TF}$, Ransohoff DF, Itzkowitz SH, Levin TR, Lavin P, Lidgard GP, Ahlquist DA, Berger BM. Multitarget stool DNA testing for colorectal-cancer screening. The New England journal of medicine. 2014; 370:1287-1297.

35. Lu H, Huang S, Zhang X, Wang D, Zhang X, Yuan X, Zhang Q, Huang Z. DNA methylation analysis of SFRP2, GATA4/5, NDRG4 and VIM for the detection of colorectal cancer in fecal DNA. Oncology letters. 2014; 8:1751-1756.

36. Park SK, Song CS, Yang HJ, Jung YS, Choi KY, Koo DH, Kim KE, Jeong KU, Kim HO, Kim H, Chun HK, Park DI. Field Cancerization in Sporadic Colon Cancer. Gut and liver. 2016.

37. Kisiel JB, Raimondo M, Taylor WR, Yab TC, Mahoney DW, Sun Z, Middha S, Baheti S, Zou H, Smyrk TC, Boardman LA, Petersen GM, Ahlquist DA. New DNA Methylation Markers for Pancreatic Cancer: Discovery, Tissue Validation, and Pilot Testing in Pancreatic Juice. Clinical cancer research. 2015; 21:4473-4481.

38. Kisiel JB, Yab TC, Taylor WR, Chari ST, Petersen GM, Mahoney DW, Ahlquist DA. Stool DNA testing for the detection of pancreatic cancer: assessment of methylation marker candidates. Cancer. 2012; 118:2623-2631.

39. Leake PA, Cardoso R, Seevaratnam R, Lourenco L, Helyer L, Mahar A, Law C, Coburn NG. A systematic review of the accuracy and indications for diagnostic laparoscopy prior to curative-intent resection of gastric cancer. Gastric cancer. 2012; 15:S38-47.
40. Liang Y, Wang W, Fang C, Raj SS, Hu WM, Li QW, Zhou ZW. Clinical significance and diagnostic value of serum CEA, CA19-9 and CA72-4 in patients with gastric cancer. Oncotarget. 2016; 7:49565-49573. doi: 10.18632/ oncotarget.10391.

41. Mukoubayashi C, Yanaoka K, Ohata H, Arii K, Tamai H, Oka M, Ichinose M. Serum pepsinogen and gastric cancer screening. Internal medicine. 2007; 46:261-266.

42. Huang YK, Yu JC, Kang WM, Ma ZQ, Ye X, Tian SB, Yan C. Significance of Serum Pepsinogens as a Biomarker for Gastric Cancer and Atrophic Gastritis Screening: A Systematic Review and Meta-Analysis. PloS one. 2015; 10:e0142080.

43. Ling ZQ, Lv P, Lu XX, Yu JL, Han J, Ying LS, Zhu X, Zhu WY, Fang XH, Wang S, Wu YC. Circulating Methylated XAF1 DNA Indicates Poor Prognosis for Gastric Cancer. PloS one. 2013; 8:e67195.

44. Oh JH, Jung SH, Hong SJ, Rhyu MG. DNA Methylation as Surrogate Marker For Gastric Cancer. Journal of cancer prevention. 2015; 20:172-178.

45. Shimwell NJ, Ward DG, Mohri Y, Mohri T, Pallan L, Teng M, Miki YC, Kusunoki M, Tucker O, Wei W, Morse J, Johnson PJ. Macrophage migration inhibitory factor and DJ-1 in gastric cancer: differences between high-incidence and low-incidence areas. British journal of cancer. 2012; 107:1595-1601.

46. Hapgood JP, Riedemann J, Scherer SD. Regulation of gene expression by GC-rich DNA cis-elements. Cell biology international. 2001; 25:17-31.

47. Pavletich NP, Pabo CO. Zinc finger-DNA recognition: crystal structure of a Zif268-DNA complex at $2.1 \mathrm{~A}$. Science. 1991; 252:809-817.

48. Crosby SD, Puetz JJ, Simburger KS, Fahrner TJ, Milbrandt J. The early response gene NGFI-C encodes a zinc finger transcriptional activator and is a member of the GCGGGGGCG (GSG) element-binding protein family. Molecular and cellular biology. 1991; 11:3835-3841.

49. Lisowsky T, Polosa PL, Sagliano A, Roberti M, Gadaleta MN, Cantatore P. Identification of human GC-box-binding zinc finger protein, a new Kruppel-like zinc finger protein, by the yeast one-hybrid screening with a GC-rich target sequence. FEBS letters. 1999; 453:369-374.

50. Tsai MH, Chen WC, Yu SL, Chen CC, Jao TM, Huang CY, Tzeng ST, Yen SJ, Yang YC. DNA Hypermethylation of SHISA3 in Colorectal Cancer: An Independent Predictor of Poor Prognosis. Ann Surg Oncol. 2015.

51. Yang X, Han H, De Carvalho DD, Lay FD, Jones PA, Liang G. Gene body methylation can alter gene expression and is a therapeutic target in cancer. Cancer cell. 2014; 26:577-590.

52. Kulis $M$, Heath S, Bibikova M, Queiros AC, Navarro A, Clot G, Martinez-Trillos A, Castellano G, BrunHeath I, Pinyol M, Barberan-Soler S, Papasaikas P, Jares P, Bea S, Rico D, Ecker S, et al. Epigenomic analysis detects widespread gene-body DNA hypomethylation in 
chronic lymphocytic leukemia. Nature genetics. 2012; 44:1236-1242.

53. Varley KE, Gertz J, Bowling KM, Parker SL, Reddy TE, Pauli-Behn F, Cross MK, Williams BA, Stamatoyannopoulos JA, Crawford GE, Absher DM, Wold BJ, Myers RM. Dynamic DNA methylation across diverse human cell lines and tissues. Genome research. 2013; 23:555-567.

54. Jones PA. Functions of DNA methylation: islands, start sites, gene bodies and beyond. Nat Rev Genet. 2012; 13:484-492.

55. Salem CE, Markl ID, Bender CM, Gonzales FA, Jones PA, Liang G. PAX6 methylation and ectopic expression in human tumor cells. International journal of cancer. 2000; 87:179-185.

56. Kim MG, Kim HS, Kim BS, Kwon SJ. The impact of old age on surgical outcomes of totally laparoscopic gastrectomy for gastric cancer. Surgical endoscopy. 2013; 27:3990-3997.

57. Huang Z, Duan H, Li H. TCGA4U: A Web-Based Genomic Analysis Platform To Explore And Mine TCGA Genomic Data For Translational Research. Studies in health technology and informatics. 2015; 216:658-662.

58. Huang T, Chen X, Hong Q, Deng Z, Ma H, Xin Y, Fang Y, Ye H, Wang R, Zhang C, Ye M, Duan S. Meta-analyses of gene methylation and smoking behavior in non-small cell lung cancer patients. Scientific reports. 2015; 5:8897.

59. Wang X, Chen JX, Liu JP, You C, Liu YH, Mao Q. Gain of function of mutant TP53 in glioblastoma: prognosis and response to temozolomide. Annals of surgical oncology. 2014; 21:1337-1344.

60. Abhinav K, Aquilina K, Gbejuade H, La M, Hopkins $\mathrm{K}$, Iyer V. A pilot study of glioblastoma multiforme in elderly patients: treatments, O-6-methylguanine-DNA methyltransferase (MGMT) methylation status and survival. Clinical neurology and neurosurgery. 2013; 115:1375-1378.

61. Berretta S, Berretta M, Fiorica F, Di Francia R, Magistri P, Bertola G, Fisichella R, Canzonieri V, Di Benedetto F, Tarantino G. Multimodal approach of advanced gastric cancer: based therapeutic algorithm. European review for medical and pharmacological sciences. 2016; 20:4018-4031.

62. Mitsuno M, Kitajima Y, Ide T, Ohtaka K, Tanaka M, Satoh S, Miyazaki K. Aberrant methylation of p16 predicts candidates for 5-fluorouracil-based adjuvant therapy in gastric cancer patients. Journal of gastroenterology. 2007; 42:866-873.

63. Lim AM, Wong NC, Pidsley R, Zotenko E, Corry J, Dobrovic A, Clark SJ, Rischin D, Solomon B. Genomescale methylation assessment did not identify prognostic biomarkers in oral tongue carcinomas. Clinical epigenetics. 2016; 8:74.
64. Albertson DG, Collins C, McCormick F, Gray JW. Chromosome aberrations in solid tumors. Nature genetics. 2003; 34:369-376.

65. Pfeufer A, Sanna S, Arking DE, Muller M, Gateva V, Fuchsberger C, Ehret GB, Orru M, Pattaro C, Kottgen A, Perz S, Usala G, Barbalic M, Li M, Putz B, Scuteri A, et al. Common variants at ten loci modulate the QT interval duration in the QTSCD Study. Nature genetics. 2009; 41:407-414.

66. Spencer KL, Malinowski J, Carty CL, Franceschini N, Fernandez-Rhodes L, Young A, Cheng I, Ritchie MD, Haiman CA, Wilkens L, Chunyuanwu, Matise TC, Carlson CS, Brennan K, Park A, Rajkovic A, et al. Genetic variation and reproductive timing: African American women from the Population Architecture using Genomics and Epidemiology (PAGE) Study. PloS one. 2013; 8:e55258.

67. Wang L, Shen H, Liu H, Guo G. Mixture SNPs effect on phenotype in genome-wide association studies. BMC genomics. 2015; 16:3.

68. Kamboh MI, Wang X, Kao AH, Barmada MM, Clarke A, Ramsey-Goldman R, Manzi S, Demirci FY. Genomewide association study of antiphospholipid antibodies. Autoimmune diseases. 2013; 2013:761046.

69. Linhares ND, Freire MC, Cardenas RG, Pena HB, Bahia M, Pena SD. Exome sequencing identifies a novel homozygous variant in NDRG4 in a family with infantile myofibromatosis. European journal of medical genetics. 2014; 57:643-648.

70. Wu D, Xu J, Yu G, Zhang B, Wang H, Wang C, Ru G, Sun A, Shen L, Wei Q. Expression status of fatty acid synthase (FAS) but not HER2 is correlated with the differentiation grade and prognosis of esophageal carcinoma. Hepatogastroenterology. 2013; 60:99-106.

71. Tang L, Wang L, Ye H, Xu X, Hong Q, Wang H, Xu L, Bu S, Zhang L, Cheng J, Liu P, Ye M, Mai Y, Duan S. gene DNA methylation contributes to the risk of type 2 diabetes in males. Experimental and therapeutic medicine. 2014; 8:459-463.

72. Eads CA, Danenberg KD, Kawakami K, Saltz LB, Blake C, Shibata D, Danenberg PV, Laird PW. MethyLight: a highthroughput assay to measure DNA methylation. Nucleic acids research. 2000; 28:E32.

73. Shen Z, Chen X, Li Q, Zhou C, Li J, Ye H, Duan S. SSTR2 promoter hypermethylation is associated with the risk and progression of laryngeal squamous cell carcinoma in males. Diagnostic pathology. 2016; 11:10.

74. Ji H, Wang Y, Liu G, Xu X, Dai D, Chen Z, Zhou D, Zhou X, Han L, Li Y, Zhuo R, Hong Q, Jiang L, Zhang X, Liu Y, $\mathrm{Xu} \mathrm{L}$, et al. OPRK1 promoter hypermethylation increases the risk of Alzheimer's disease. Neuroscience letters. 2015; 606:24-29. 